\title{
ハードクレーによるアセトンのアルドール 縮合反応
}

(昭和47年 6 月19日 受理)

\section{川崎 仁士*板 谷 克 彦* 草 野 文 男* 児 玉 総 治*}

要 旨 ハードクレーに付着している有機物の除去を目的に，ハードクレーをアセトンで抽出処理を行な ったところ，ハードクレーはアセトンのアルドール形縮合反応の触媒作用を有することを見い出したので， この点について検討した.

アセトンの縮合生成物は主成分がジアセトンアルニールで，一部メシチルオキサイドも生成している。シ アセトンアルコールの生成から，ハードクレーは一般に認められている固体酸としての性質をもつ以外に， 固体塩基としての性能も有していることを推定した。 ハードクレーとンフトクレー間には，アルドール形縮 合反応触媒能に大きな差が認められた。 またハードクレーを配合したゴムを用い，アセトン宿合能について も椧討を加えた。

\section{1. 緒言}

アメリカ南カロライナ州のアイケン付近に笙出するカ オリン系粘士鉱物は，合成ゴムに充てん剤として配合し た場合，他の地城から産出するカオリン系粘土鉱物と比 較して，相当寸ぐれた物理的性質を示すことが一般に㒛 められている。しかしこの粘士（ハードクレー）のゴム に対する補強要因については，いまだ明確になされてい ないのが現状である．著者らも，この補強要因を明らか にする目的で以前から検討を続け，この補強性の良い力 オリン系粘土鉣物，いわゆるハードクレーとSBR間に 相互作用が存在することを前報》で明らかにしてきた が，八ードクレー表面のいかなる点がこの相互作用に関 与しているかについてはいまだ不明である。

またハードクレーと，補強性の劣る粘土，いわゆるy フトクレーの成因をながめて見ると，前者は後者よりを 風化のよく進んだ爑積粘土，すなわち二次粘土と呼ばれ るものである点を考えると，表面に付着している有機物 も他の粘土より多いことが予想される，そこでこれらの 有機物が補強性に与える影響についても明らかにされる 必要があろう。著者らはこの吸着している有機物の除去 を種々な溶舤を用いて行なったところ，ハードクレーを

†本報を[ハードクレーの特性に関する研究（第 5 報)」とする.

* 岡山嫘工業試験場

(\$700 岡山市伊福町 4 丁目 3 の18)
アセトンで抽出処理を行ならと，異常とも思えるほどの 抽出物が存在することを見いだした。この抽出物につい て同定を行なったところ，ハードクレーが触媒となっ て，アセトンがアルドール形縮合を抗こして，ジアセト ンアルコールとメシチルオキサイドが生成することを認 めた。このようにハードクレーがアセトンを二量体化す る性質があるとなると，ゴム試験法に定められているア セトン抽出量 ${ }^{2)}$ むードクレー配合物について問題にな ってくるので，この点についても合わせて検討を加えた 結果を報告する。

\section{2. 実 験 方 法}

\section{1 試 料}

ハードクレーはクラウンクレーを使用し，一部ディキ シクレーを用いた。 またソフトクレー*1として SPSク レー（末処理）とASPクレー（好理不明）を用いた.

アセトンは試藻特級をそのまま用いた。

\section{2 アセンン縮合物の製造}

ソックスレー抽出器を用い，東洋ろ紙 No. 84 の円筒 ろ紙中に所定量のクレーを入れ，アセトン $100 \mathrm{ml}$ で適 当な時間抽出操作を行ない，アセトン縮合物をつくっ tit.

\footnotetext{
*1 輸入されているカオリン系クレーは, ハードクレ 一以外はほとんど製紙用のものが中心で，この製 紙用のカオリン系クレーは何んらかの前処理がほ どこされているものが多い.
} 


\section{3 生成物の同定}

ガスクロマトグラフィーは日立製K一 $\mathrm{K}$ 型により， $\mathrm{TCD}$ キャリヤーガス: He $(30 \mathrm{ml} / \mathrm{min})$,カラム : DEG BPE $15 \%(2 \mathrm{~m}) .120^{\circ} \mathrm{C}$ で行なった.

IR スペクトルの測定は日本分光製の IR-G 型を用い, $\mathrm{KBr}$ 板にはさんで測定した。 また一部 $\mathrm{KBr}$ 固定セルも 用いた NMR，スペクトルの測定は日立製の核磁気共 鸣装置 R-20 形を用い，10\%の四塩化炭素溶液で測定し た.

\section{3. 結果と考察}

\section{1 生成物の同定}

クラウンクレー20 g を用い，40時間抽出処理を行なっ た後，減压下゙末反応のアセトンを除去したものについ てガスクロマトグラムを測定し，結果を図1に示した。 図 1 から抽出物中には保持時間が 1 分のアセトンのピー ク以外に，2分上7分儿ピーク肪認められ，かつ後者の ピークを与える物翼が主生成物であることがわかる。を こでこの主成分をガスクロマトグラフを用いて分取し，

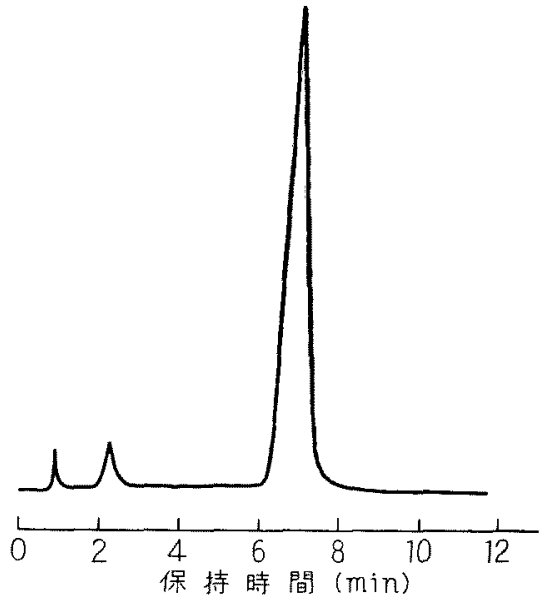

図 1 生成物のガスクロマトグラム(インジェクシ ヨン: $160^{\circ} \mathrm{C}$ ，力ラム温度 : $120^{\circ} \mathrm{C}$ )

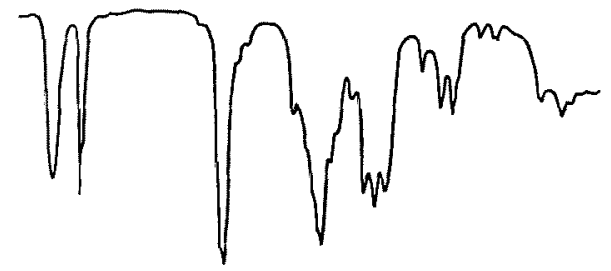

$40003000200018001600 \quad 140012001000800: 600400$ 波 数 $\left(\mathrm{cm}^{-1}\right)$

因 2 主成分のIＲス゚クトル
その 1 Rスペクトルと NMR スペクトルを測定した. 結果を図 2 ，図3に示寸。

図 2 で, 主生成物には $3450 \mathrm{~cm}^{-1}$ 付近の吸收から $\mathrm{OH}$ 基の存在が認められ，また $1150 \mathrm{~cm}^{-1}$ の吸收からこれ が第 3 級アルコールである点もわかる. $1700 \mathrm{~cm}^{-1}$ 付近 の吸收からは $\mathrm{C}=\mathrm{O}$ 基の存在が, $1380 \mathrm{~cm}^{-1}$ 付近の吸収 が 2 本に分かれていることから $-\mathrm{C}\left(\mathrm{CH}_{3}\right)_{2}-$ の存在が認 わ方加，加 $1360 \mathrm{~cm}^{-1}$ の強度肪 $1380 \mathrm{~cm}^{-1}$ より 女大 $\mathrm{O}$

であることから， $\mathrm{C}-$ Ć- $\mathrm{CH}_{3}$ 基が存在していることがわ かる、一方図 3 の NMR スペクトルの結果では，3.42, 2.54, 2.12, 1.16 PPM に吸收が認められた。これらの吸 収は，図 2 の結果より推定されるジアセトンアルコール (以下 DA と略す) の文献值 ${ }^{32}$ と一致している.また図 2 のR スペクトルも標準試薬の DA の IR スペクトル 上一致した.

次にガスクロマトグラフを用い，四塩化炭素中に図1 の保持時間 2 分の物質分取 し， $0.5 \mathrm{~mm}$ の $\mathrm{KBr}$ 固定 セルを用いて IR スペクトルを測定し結果を図4に示し

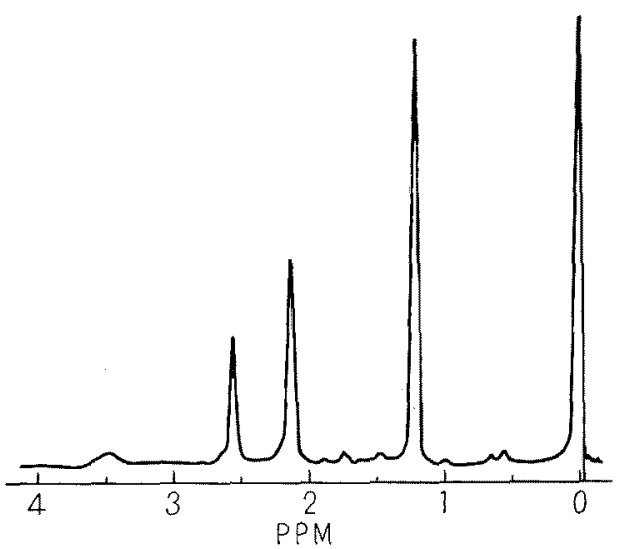

図 3 主成分のNMRスペクトル

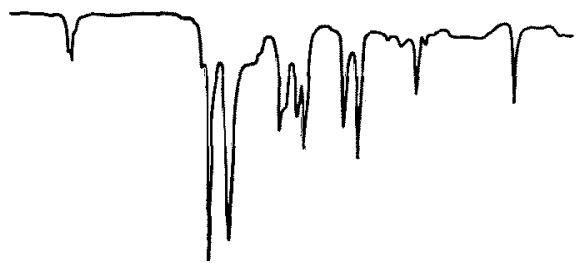

40003000200018001600140012001000800600400 波数 $\left(\mathrm{cm}^{-1}\right)$

図 4 従成分のIRスペクトル 
た。図 4 の $1690,1620 \mathrm{~cm}^{-1}$ 付近に認められる吸収は Theus ら" によると ${ }_{\mathrm{H}}^{\mathrm{R}}>\mathrm{C}=\mathrm{C}<{ }_{\mathrm{H}}^{\mathrm{COCH}}{ }_{3}$ 型の $\nu_{C=0}$ と $v_{c \bullet C}$ の振動に起因する吸収であるといわれている，ま た酸性触媒ではアセトンの縮合物として，メシチルオキ サイド（以下 MO と略す）ができるといわれている5). 以上の 2 点を考慮するとクラウンクレー表面の酸性点が 触媒作用をして，MOが生成していることが予想され る. そこで標準試薬の MOのIR スペクトルを測定し たところ図 4 と一致した。

以上の結果より明らかなごとく，ハードクレーをアセ トンで抽出処理をした場合，ハードクレーがアセトンの アルドール形縮合反応の触媒となって，主としてDA を 生成するが一部 MO も生じることが判明した。

\section{2 抽出処理時間と DA の生成量}

3.1 で明らかにした MO 上 DA の蒸気圧は，それぞ れ 8.7, $1.1 \mathrm{mmHg}\left(20^{\circ} \mathrm{C}\right)$ である点を考えると, 減圧下 でアセトン除去操作中に蒸発して，アセトンと共に除去 されることが予想される. ガスクロマトグラムからアセ トン除去割合に対するこれら両者の割合を測定したとこ ろ MO は大幅に減少するが，DA はほとんど変化は認 められなかった．そこで一応減圧下でアセトン除去を行 なっても，DA の生成量には大差はないものと考えて， クラウンクレー20 $\mathrm{g}$ と一定にし，抽出処理時間に対する DA の生成量を求め図 5 に示した。 図 5 より明らかなご とく, DA の生成量は抽出処理時問が60時間ぐらいまで はほぼ直線的に増大し，以後緩慢な増加傾向にある。一 方 100 時間抽出処理しても，生成量は $2.5 \mathrm{~g}$ 程度で一般 の DA の製造法可に比して收率はよくない。

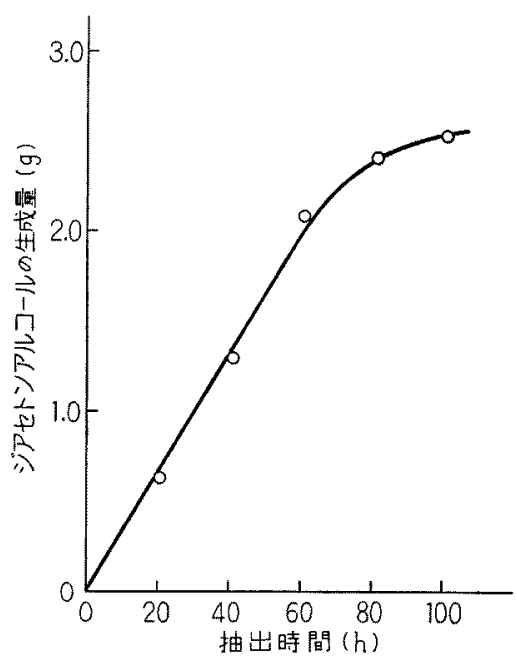

図 5 抽出時閒とジアセトンアルコールの生成量

\section{3 クレーの変量効果}

抽出処理時閒を40時間に選び，クラウンクレーを変量 した場合の DA の生成量を求め，単位表面積当りに换算 した結果と合わせて図 6 と示した. 図 6 より，DA の生 成量流クレー量と一次の関係があり,クレ一量が増大す るほど増加する傾向が認められる，一方単位表面積 $\left(\mathrm{N}_{2}\right.$ ガス吸着法によりクラウンクレーの表面積を求めたとこ ろ $23 \mathrm{~m}^{2} / \mathrm{g}$ であった）当りに換算してみると，クレー の変量による差はほとんど認められなくて2.0〜2.5× $10^{-3} \mathrm{~g} / \mathrm{m}^{2}$ とほぼ一定である。このことからアセトンのア ルドール化縮合反応に関与する触媒活性点は, クレー表 面に均一に分布していることがわかる，

\section{4 クレーの種類の影響}

クラウンクレー以外のハードクレーとしてディキシク レーを, ソフトクレーとして SPS タレーと ASP クレー を選び，また Grenhall' や Holm ら”の方法に準してて， クラウンクレー表面のブロンステッド酸点を $\mathrm{Na}^{+}, \mathrm{NH}_{4}{ }^{+}$ で交換したものや，焼成クレー $\left(600^{\circ} \mathrm{C}\right)^{13}$ について，ア ルドール化縮合反応の触媒能について検討を加え, 結果

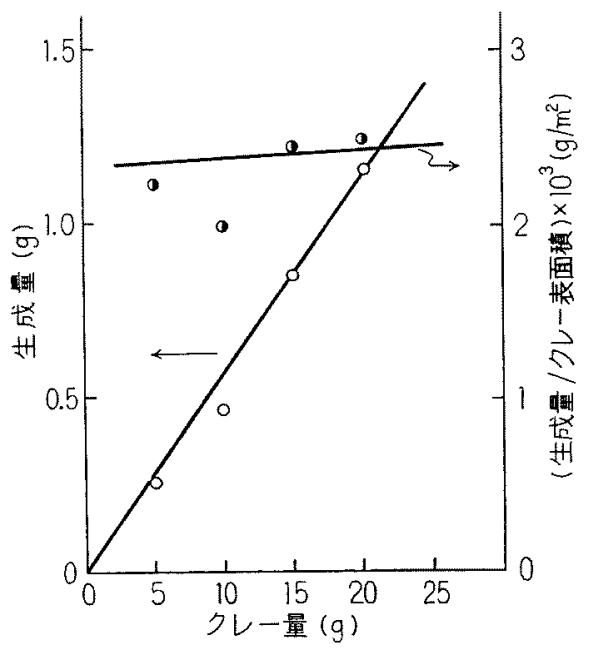

図6 クレー量とジアセトンアルコールの生成量

表 1 各種クレーのアセトン縮合能

\begin{tabular}{|c|c|c|c|c|}
\hline クレーの種類 & クレー量 & $\frac{\text { 処理時間 }}{(\mathrm{b})}$ & 縮 $\underset{(\mathrm{g})}{(\mathrm{g})}$ & $\begin{array}{l}\text { MOO } \\
\text { 確認 }\end{array}$ \\
\hline クラウンクレー & 20 & 40 & 1.33 & 有 \\
\hline ディキシクレー & 20 & 40 & 1.45 & 有 \\
\hline A S Pクレー & 20 & 40 & 0.01 以下 & - \\
\hline SPSクレー & 20 & 40 & 0.08 & 有 \\
\hline 焼成クレー & 20 & 40 & 0.01 W. & - \\
\hline $\mathrm{Na}$-交換クレー & 20 & 20 & 0.50 & 無 \\
\hline $\mathrm{NH}_{4}$-交換クレー & 20 & 40 & 1.41 & 無 \\
\hline
\end{tabular}


を表 1 に示した．ただし表1のアセトン縮合物量は減圧 下でアセトン除去後の収量でもって示した，MOの確認 はアセトン除去前の試料について調べた。

表1からかかるように，ディキシクレーもクラウンク レーと同じような結果が得られている。一方同じカオり ン系粘士鉱物でむソフトクレーにおいては, 縮合物量が ハードクレーの場合と比較して非常に少ない，この現象 と合成ゴムに対する補強性の差異とを対比してみると興 味ある結果と思われる．焼成クレーに招いてもンフトク レーと同じ結果が得られている。 また $\mathrm{Na}, \mathrm{NH}_{4}$ 交換り レーには MO の生成が認められなかった。この結果よ り，クレーをアセトンで抽出処理している閪にできる MOの方は，クレー表面に存在するブロンステッド酸点 が触媒作用をしていることが推察される。

\section{5 熱処理温度と DA, MO の関係}

クラウンクレーは約 $1.2 \%$ 程度の平行水分を含有して 扔り，これら水分が先述してきたアセトンのアルドール 形縮合反応俍響を及ぼすことも考えられる 処理により吸着水分を除去したものについて，カールフ イシャ一法で測定した残留水分, 生成物中にしめる DA とMOの生成割合（アセトン除去前の試料のガスクロ マトグラムから求めた）および DAの生成量を求め表 2 に示した．結果はいずれもクレー20 g，40時間抽出処理 したものである。

表 2 で，生成物中にしめるMO の割合は，熱処理温

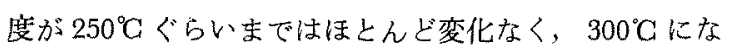
ると急激に增大している。 DA の生成是注処理温度が $100 \sim 200^{\circ} \mathrm{C} く$ らいまでに極大があり, 以後低下し $600^{\circ} \mathrm{C}$ ではほとんど無に近かった（表 $1 ，$ 焼成クレー参照)。こ のように熱処理温度が $300^{\circ} \mathrm{C}$ で，生成物中にしめるMO の含有割合が急增しているのは，ブロンステッド酸点の

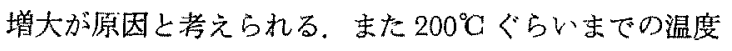
で脱水処理したものは，未処理のものに比べてDAの生 成量が 5 倍ほども多くなっていることから，クレー表面 ○吸着水分が触媒活性の低下に関倸し、ていることがかか

\section{表 2 熱処理温度の影響}

\begin{tabular}{rrrrr}
\hline $\begin{array}{c}\text { 処理温 } \\
\left({ }^{\circ} \mathrm{C}\right)\end{array}$ & $\begin{array}{c}\text { 残留水分 } \\
(\%)\end{array}$ & $\begin{array}{r}\text { MO } \\
(\%)\end{array}$ & $\begin{array}{l}\text { DA } \\
(\%)\end{array}$ & $\begin{array}{r}\text { DAの生 } \\
\text { 成量 }(\mathrm{g})\end{array}$ \\
\hline 未処理 & 1.50 & 3.2 & 91.8 & 1.05 \\
100 & 0.24 & 8.5 & 91.5 & 5.02 \\
150 & 0.08 & 9.8 & 90.2 & 5.62 \\
200 & 0.05 & 10.3 & 89.7 & 5.63 \\
250 & 0.04 & 12.3 & 87.7 & 1.59 \\
300 & 0.02 & 21.7 & 78.3 & 1.21 \\
\hline
\end{tabular}

る. また $200^{\circ} \mathrm{C}$ 以上の高温で処理するとかえって DAの 生成量墭少していることから，クレーに付着している 有機物が DA の生成に関与しているとも考えられる。 そ こで $10 \% \mathrm{NaOH}$ で処理し，クレーに付着している有機 物を除去後 ${ }^{9}$ ，塩酸処理，充分水沙乾燥させたものを $100^{\circ} \mathrm{C}$ で 3 時間熱処理したものについて，アセトンの縮 合能を調べたところ DA む MO る認められた。このよ らに $\mathrm{NaOH}$ 処理しても DA の生成能は有しているし, 区面その生成量は減少したところをみると，これだけの 結果から DA の生成上付畕有機物の関係索結諭つけるの は困難である。この問題については今後の検討にまちた ?.

いずれにしても以上述べてきたように，ハードクレー はアセトンのアルドール化縮合反応の触媒作用を有して いる．またその縮合主生成物は DA であるし，DA は触 媒が塩基であるときにのみ生成するといわれているらここ とから，ハードクレー表面に注酸性点のみならず塩基性 点の存在む推定される。乙こでこの塩基性点が触媒とな りアセトンは式(1)に示すように縮合し，DA が生成する ものと考えられる

\section{$2 \mathrm{CH}_{3} \mathrm{COCH}_{3} \longrightarrow\left(\mathrm{CH}_{3}\right)_{2} \mathrm{C}(\mathrm{OH}) \mathrm{CH}_{2} \mathrm{COCH}_{3}$}

他方 MO の方は，ハードクレー表面のブロンステッ ド酸点を被毒したものでは生成しないことから，表面の ブロンステッド酸点が触媒となって式(2)に示すよらに生 ずるものと考えられる

$$
\begin{array}{r}
2 \mathrm{CH}_{3} \mathrm{COCH}_{3} \longrightarrow \\
\left(\mathrm{CH}_{3}\right)_{2} \mathrm{C}
\end{array}=\mathrm{CHCOCH}_{3}+\mathrm{H}_{2} \mathrm{O}
$$

\section{6 配合ゴムの場合}

SBR 1502 にクラウンクレー 100 部を配合したゴムを つくり，この20 gを小さく切って円筒万紙に入れて同様 な操作を行ない，その抽出物からアセトンを除去した むのについて IR スペクトルを測定し結果を図7に示し た.

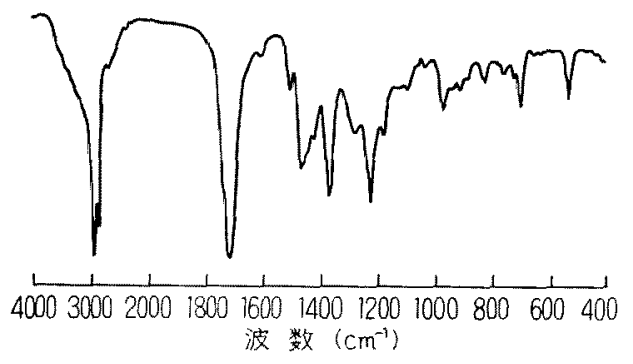

図 7 アセトン抽出物のI Rスペクとル (クレー配 合ゴム) 
図7には，図2に示してあるDAの吸収は認められな い. またガスクロマトグラムからも DA や MO と同し 保持時間にピークは認められなかった。このことはゴム にクレーを配合した場合, クレー表面の触媒活性点にゴ ムが吸着されていることや，クレーとアセトンの接触が うまくいかないことに原因があると考えられる. 以上要 するに，ゴムに配合した場合には，DA や MO の生成 を心配しなくてもよいことが判明した。

\section{4. 結言}

ハードクレーはアセトンをアルドール縮合させる能力 があることを見いだした，その縮合生成物は DA と MO であり，かつ主成分はDAであることを明らかにした。 この結果より，ハードクレーは一般にいわれているよう に固体酸としての性㬅以外に，固体塩基としての性質も 有していることを推定した．同じカオリン采粘土鉱物で む，ハードクレーとソフトクレーでは，アセトンのアル ドール縮合反応能に大きな相違が認められた。 ハードク レー配合ゴムのアセトン抽出物中には DA や MO の生 成は認められなかった。

最後に，本研究を行なうにあたり，ご指導，ご校閲を
賜った大阪府立放射線中央研究所, 第二部部長鈒害夫工 博，NMR スペクトルを測定していただいた大阪府立大 学工学部小松紀陸工博, およびクレー試料の入手でお世 話になった，太陽ゴム工業所技術部長妻鹿菊夫氏に深く 感謝いたします。

\section{文献}

1) 川崎仁士，板谷克彦，草野文男，巟玉総治： 日ゴム協誌，45, 64 (1972)

2) 日本ゴム協会編：ゴム試験法，p. 584 (1963)

3) NMR Data Tables of Organic Compounds, Vol. 1 (Interscience Pub.)

4) V. Theus, W Surber, L. Colombe, H. Schinz: Helv. Chim. Acta., 38, 239 (1955)

5) 小方芳郎：有機反応諭, p. 289, 丸善 (1960)

6) A. Grenhall: Ind. Eng. Chem., 41, 1485 (1949)

7) V. C. F. Holm, G. C. Bailey, A. Clark: $J$. Phys. Chem., 63, 129 (1959)

8) 川崎仁士，板谷克彦，畑宏，草野文男：日 ヨ゙ム協誌，44, 59 (1971)

9）日本粘土学会編：粘土ハンドブック，p. 534 技報堂 (1967)

10) H. Niiyama, E. Echigoya: Bull. Chem. Soc. Japan, 44, 1739 (1971)

\section{STUDIES ON CHARACTERIZATIONS OF CLAY (V)}

\section{THE ALDOL CONDENSATION REACTION OF ACETONE BY HARD CLAY}

\section{Hitoshi Kawasaki, Katsuhiko Itadani, Fumio Kusano, Soji Kodama (Okayama Indus- trial Research Institute, No. 3-8, 4-chome Ifukumachi, Okayama, 700, Japan)}

Hard clay was treated with Soxhlet-apparatus in order to remove the organic impurities. It was found in this process that hard clay catalyzes the aldol-type condensation reaction of acetone. The main product of this condensation reaction was diacetone alcohol. A small amount of mesityl oxide was obtained as byproduct.

It has been well known that hard clay is a solid acid, but the results, showed that hard clay can act as a solid base. There was a marked difference in the ability to catalyze the aldol-type condensation reaction of acetone between hard clay and soft clay. Hard clay loaded in SBR showed no catalyzation ability for the aldol-type condensation reaction of acetone. 